CLINICAL CASE

\title{
MALE PSEUDOHERMAPHRODITISM: CASE REPORT
}

\author{
Cristina Moisei ${ }^{1}$, Anca Lesnic ${ }^{1}$, Romina-Marina Sima ${ }^{1,2}$, Cristian Bălălău ${ }^{2,3}$, Liana Pleşs ${ }^{1,2}$ \\ ${ }^{1}$ Clinical Hospital "Sf. Ioan "," Bucur "Maternity, Bucharest, Romania \\ ${ }^{2} \mathrm{UMF}$ "Carol Davila", Bucharest, Romania \\ ${ }^{3}$ Clinical Hospital "Sf. Pantelimon" Bucharest
}

Corresponding author: Romina-Marina Sima Email: romina.sima@yahoo.es

\begin{abstract}
A pseudohermaphrodite represents a human being whose gonads are consistent with the chromosomal sex but who has external genitalia resembling the opposite sex. Male pseudohermaphrodites are characterized by normal testes with insufficient masculinization of the wolffian duct system and external genitalia. Patients with female pseudohermaphroditism have female internal genitalia and karyotype $(X X)$ and various degree of external genitalia virilization. We present the case of a fetus with male pseudohermaphroditism, detected at 21 weeks of pregnancy during the second trimester morphology exam, with no other anomalies present. The peculiarity of this case is represented by the fact that the initial supposition was of clitoral hypertrophy (female pseudohermaphroditism), but after amniocentesis incomplete masculinization causes are being explored (male pseudohermaphroditism).
\end{abstract}

KEYWORDS: pseudohermaphroditism, clitoral hypertrophy, amniocentesis, karyotype

\section{INTRODUCTION}

A pseudohermaphrodite represents a human being whose gonads are consistent with the chromosomal sex but who has external genitalia resembling the opposite sex. Male pseudohermaphrodites are characterized by normal testes with insufficient masculinization of the wolffian duct system and external genitalia. One form of this condition is the inherited disorder androgen insensitivity syndrome (AIS), also called testicular feminization syndrome. These individuals have normal testes and karyotype (46:XY), their testes secrete normal amounts of testosterone, but the genetic absence of the receptors for androgens in target tissues leads to developing. Female-like external genitalia, the cryptorchidism, and wolffian duct structures (epididymis, vas deferens, and seminal vesicles) are absent. The most frequent type of pseudohermaphroditism is represented by the apparent shift of sex at puberty. The Guevedoces syndrome, also known as 5areductase deficiency, is relatively common in several isolated villages is the Dominican republic; Guevedoces translates to penis at 12, the individuals are genetic male, but because of the deficient 5a-reductase, their true sex begins to unfold at puberty.

Persons with female pseudohermaphroditism are characterized by karyotype (XX), female internal genitalia and various degrees of external genitalia virilization. The external genitalia are masculinized congenitally when female fetus is exposed to excess androgenic environment. Congenital adrenal hyperplasia $(\mathrm{CAH})$ may be the consequence of 21-hydroxylase deficiency, as the usual cause. Maternal ovarian tumor may secrete maternal 
androgen excess or drug intake can also cause female pseudohermaphroditism [2].

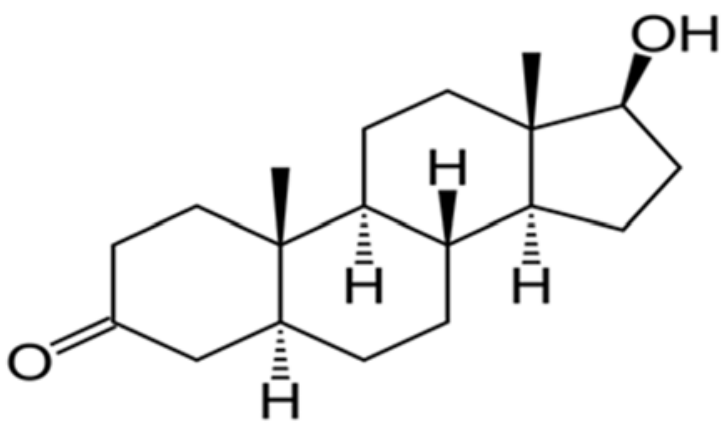

Figure 1 - DHT/ dihydrotestosterone - the product of 5a-reductase

\section{MATERIALS AND METHODS}

We present the case of a fetus with male pseudohermaphroditism, detected at 21 weeks of pregnancy during the second trimester morphology exam, with no other anomalies present.

\section{RESULTS}

An IGIP gravida presented at 21 weeks for the anomaly scan. The external genitalia examination revealed abnormal appearance: abnormal penis mimicking clitoromegaly, absence of testis in the scrotal folds. On the sagittal section the penile structure pointed up and no uterine structure was present on transverse section. The gravida has no history of illness or medication taken for chronic disease before or during this pregnancy. In order to establish the genetic sex the patient was referred for a second opinion and also a genetic specialist counseling. Amniocentesis was performed and the result was that the fetus was $46 \mathrm{XY}$, with a normal diploid number for chromosomes 13, 18 and 21. The fetus was delivered at 37 weeks of pregnancy via Csection, and the evolution was uneventful. The baby had scrotal fold inhabited by testis and an abnormal penile structure - hypospadias. The couple was counseled to ask for a pediatric surgeon examination and close following of the baby for the next 2 years.

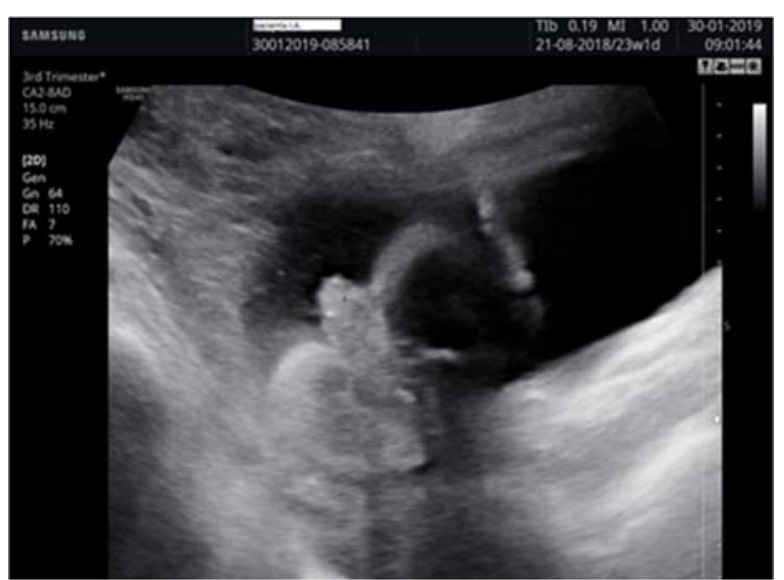

Figure 2 - Ultrasound image suggesting clitoral hypertrophy at 23 weeks of pregnancy and the absence of testes.

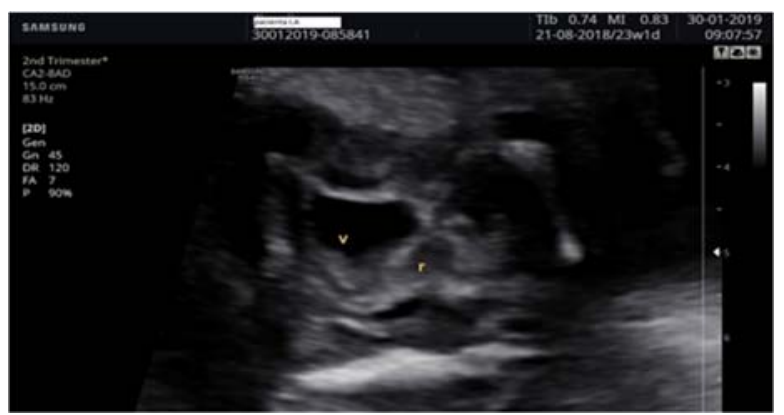

Figure 3 - Ultrasound image of the fetal pelvis. The small distance between the rectum and the bladder suggests the absence of the uterus and adnexae.

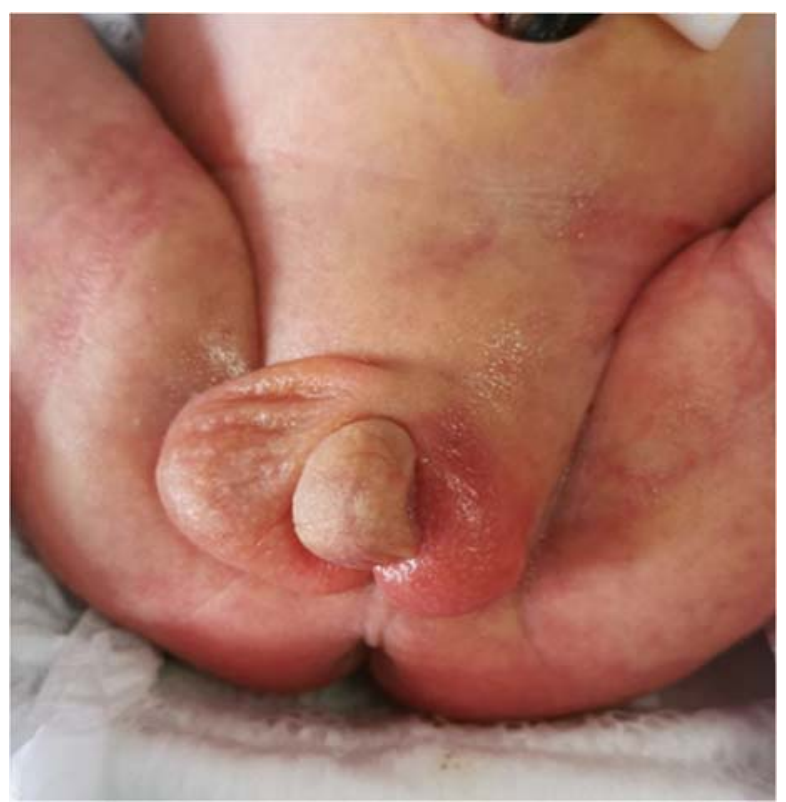

Figure 4 - The appearance of the external genital immediately after birth (hypospadias present, descended testes but abnormal scrotum). 


\section{DISCUSSION}

The most common cause of female pseudohermaphroditism is congenital adrenal hyperplasia, other causes like exogenous androgens, excess placental androgen production and idiopathic comprising a small percent of cases [3]. When talking about male pseudohermaproditism the most known cause is inherited disorder androgen insensitivity syndrome (AIS), also called testicular feminization syndrome [3].

When trying to differentiate the different types of ambisexual development it is vital in earliest infancy to differentiate female pseudohermaphroditism due to congenital adrenal hyperplasia (by dosing on the basis the 17-ketosteroid excretion), from other forms of ambisexual development. In case of congenital adrenal hyperplasia the treatment is with cortisone according to standard protocols. Surgical intervention is recommended in case of enlarged clitoris, and it should be removed before school age and the urogenital sinus corrected to form a separate vagina. The continuous corticotherapy may determine normal female development. If the adrenogenital syndrome has been excluded, all patients with ambiguous genitalia should be submitted to careful urethroscopic study and exploratory laparotomy. This applies also to individuals who appear to be cryptorchid males with hypospadias and those resembling females with gonads in the groins or labia. These interventions should be considered in the first months of life and a definite decision made as to the sex in which the child is to be considered. Accordingly, every effort should be made in early infancy to decide the sex of rearing and the parents should be given support, guidance and reassurance by a multidisciplinary team. Corrective interventions should be performed as early as possible. Changes from the first decision are established in later childhood with caution.

Male pseudohermaphrodites who have external genitalia of female configuration invariably feminize at puberty, so that orchiectomy is not necessary to prevent masculinization but it is recommended to avoid the possible risk of testicular malignancy [4].

\begin{tabular}{|c|c|}
\hline $\begin{array}{l}\text { Complete androgen } \\
\text { insensivity (XY) }\end{array}$ & $\begin{array}{l}\text { Partial androgen } \\
\text { insensivity }(\mathrm{XY})\end{array}$ \\
\hline $\begin{array}{l}\text { Female body hair } \\
\text { pattern }\end{array}$ & $\begin{array}{l}\text { Sparse body and facial } \\
\text { hair }\end{array}$ \\
\hline $\begin{array}{l}\text { Breast development } \\
\text { Undescended testes }\end{array}$ & $\begin{array}{l}\text { Rudimental breast } \\
\text { development }\end{array}$ \\
\hline $\begin{array}{l}\text { No uterus, fallopian } \\
\text { tubes }\end{array}$ & $\begin{array}{l}\text { Undescended testes } \\
\text { Hypospadias with a }\end{array}$ \\
\hline $\begin{array}{l}\text { No vas deferens, } \\
\text { epididymis, seminal } \\
\text { vesicles }\end{array}$ & $\begin{array}{l}\text { small scrotum } \\
\text { Infertility and sexual } \\
\text { dysfunction }\end{array}$ \\
\hline $\begin{array}{l}\text { Short vagina with } \\
\text { female } \\
\text { genitalia }\end{array}$ & $\begin{array}{l}\text { Male or female gender } \\
\text { identity }\end{array}$ \\
\hline sender identity & \\
\hline $\begin{array}{l}\text { ductase } \\
\text { cy } \\
\text { loces) }\end{array}$ & $\begin{array}{l}\text { tal adrenal } \\
\text { asia }(\mathrm{XX})\end{array}$ \\
\hline Bef & ive body \\
\hline $\begin{array}{l}\text { Female } \\
\text { genitalia }\end{array}$ & $\begin{array}{l}\text { facia } \\
\text { Deep }\end{array}$ \\
\hline $\begin{array}{l}\text { Small prostate } \\
\text { Undescended te }\end{array}$ & $\begin{array}{l}\text { Rudimental } \\
\text { development }\end{array}$ \\
\hline y raised as girls & Ovaries, \\
\hline uberty: & terus present \\
\hline Male facial and body & clitoris \\
\hline hair & \\
\hline Penis enlargement & Usually female gender \\
\hline led testes & \\
\hline Prese & \\
\hline Male & \\
\hline
\end{tabular}

Table 1 - Most common causes and presentations of pseudohermaphrodites [1].

\section{CONCLUSIONS}

The peculiarity of this case is represented by the difficulty to differentiate between female pseudohermaphroditism and male pseudohermaphroditism due to the ultrasound appearance of the external genitalia. The amniocentesis ruled out the first option and incomplete masculinization causes were being explored. The treatment has to be individualized and performed by a multidisciplinary team. The patient can benefit from hormonal treatment. Because the gender identity usually is established before 24 months, any switch after that mark must be carefully evaluated. The undescended testes must be removed because of the risk of neoplasia, and any other 
abnormalities, for example hypospadias must be surgically corrected in the first year of life.

\section{REFERENCES}

[1] Jones R, Lopez K, Human Reproductive Biology (Fourth Edition), 2014
[2] Kamijo H. Female pseudohermaphroditism https://www.ncbi.nlm.nih.gov/pubmed/9396289

[3] Horii M, Parast M. , Female Genital Tract Development and Disorders of Childhood in Diagnostic Gynecologic and Obstetric Pathology (Third Edition), 2018

[4] Wilkins L, Grumbach M, Van Wyk J., Shepard T, Papadatos C. Hermaphroditism: Classification, Diagnosis, Selection of Sex And Treatment 